\title{
Physical and technological characterization of the wood of candidate clones of Eucalyptus urophylla
}

\section{Caracterización física y tecnológica de la madera de clones candidatos de Eucalyptus urophylla}

ORTEGA-RAMIREZ Marynor Elena $\dagger^{*}$, TORRES-LAMAS, Secundino, MENDEZ-ARCOS, Jorge Luis and ARCOS RAMIREZ, Jorge Alexys

Universidad Autónoma de Chiapas - Forestaciones Operativas de México S.A de C.V.

El Colegio de la Frontera Sur Unidad Villahermosa

Forestaciones Operativas de México S.A de C.V.

ID $1^{\text {st }}$ Author: Marynor Elena, Ortega-Ramírez / ORC ID: 0000-0002-2551-4054, Researcher ID Thomson: S-4732-2018 CVU CONACYT ID: 446579

ID $1^{\text {st }}$ Coauthor: Secundino, Torres-Lamas / ORC ID: 0000-0002-1060-7776, CVU CONACYT ID: 639341

ID $2^{\text {nd }}$ Coauthor: Jorge Luis, Méndez-Arcos / ORC ID: 0000-0002-9641-8836, CVU CONACYT ID: 1039455

ID $3^{\text {rd }}$ Coauthor: Jorge Alexys, Arcos-Ramirez / ORC ID: 0000-0002-6237-5065

DOI: $10.35429 / J A N R E .2020 .7 .4 .11 .15$

Received October 14, 2020; Accepted December 03, 2020

\begin{abstract}
The aim of this work was to evaluate the basic density of wood from candidate clones of Eucalyptus urophylla, in Huimanguillo, Tabasco. Eleven different genotypes of five and 12 years old were studied. Two methodologies were used, the empirical method and by water displacement. The density of wood in the genotypes ranged from 0.38 to $0.63 \mathrm{~g} \mathrm{~cm}-3$ which is catalogued as light to very light. The variation in basic density between clones and the methodologies used was not significant.
\end{abstract}

\begin{abstract}
Resumen
El presente trabajo tuvo como objetivos evaluar la densidad básica de la madera de clones candidatos de Eucalyptus urophylla, en Huimanguillo, Tabasco. Se estudiaron 11 genotipos diferentes de cinco y 12 años de edad. Se emplearon dos metodologías, el método empírico y por desplazamiento en agua. La densidad de la madera en los genotipos osciló entre 0.38 y $0.63 \mathrm{~g} \mathrm{~cm}^{-3}$ que es catalogada como liviana a muy liviana. La variación de la densidad básica entre clones y las metodologías empleadas no fue significativa.
\end{abstract}

Clones, Densidad, Eucalyptus

\footnotetext{
* Correspondence to Author (email: marynor.ortega@ gmail.com)

$\dagger$ Researcher contributing as first author.
} 


\section{Introduction}

The genus Eucalyptus is one of the most used in commercial forest plantations (PFC) due to the goodness of the wood for various uses that several species of this genus present. The municipality of Huimanguillo, Tabasco presents favorable conditions for the development of Eucalyptus species with a warm climate. Eucalyptus urophylla has been one of the most widely planted in recent decades due to its good growth in the region. Its use has been mainly in the pulp industry and currently for the production of medium density fibreboard (MDF, for its acronym in English).

Generally, in genetic improvement programs, the traits of greatest interest that are selected are those linked to growth and the shape of the trees, since they are directly linked to the productivity and economic performance of PFCs (Alarcón et al., 2018 ). However, there has been an interest on the part of forest managers to increase the range of end products that can be obtained from the wood produced in PFCs. This would increase the profitability of the plantations since the wood would be given greater added value with products of higher economic value.

One of the characteristics that define the quality of the wood, and that has taken on greater relevance, is the basic density, regardless of the final destination, either for the production of pulp or solid wood. The basic density is an indicator of the quality and performance of wood and its derivatives (Arango et al., 2001). In addition, it is a coefficient that allows the transformation of the volume of green wood to dry matter, this is important, since it is a starting point to estimate carbon stores in standing trees (Muñoz et al., 2019).

It has been found that the basic density varies due to various factors such as management, species, genotype, and even position within the tree (Muñoz et al., 2019). Omonte et al., (2019) found that the basic density in Eucalyptus nitens trees was generally lower in the upper part of the trees and in wood close to the bark. Eufrade-Junior et al., (2017) evaluated the effect of planting density and fertilization on the basic density of Eucalyptus urograndis. The authors found that the basic density was higher in the plots with less dense spacing, and in those where the fertilization dose was higher.
Eucalyptus urophylla in Huimanguillo achieve + growth rates in volume greater than 30 $\mathrm{m} 3$ ha-1 year-1 (CONAFOR and AMEPLANFOR, 2016). Despite the fact that most of this wood is used to make MDF, previous studies mention that E. urophylla wood has excellent characteristics as structural wood for construction (Lahr et al., 2017), cellulose for paper (Souza et al., 2017), and to obtain coal (Marchesan et al., 2020).

In Mexico, few studies have been done that address the physical properties of Eucalyptus urophylla wood, especially those related to basic density. Due to the good growth that the species shows and the goodness of its wood, it is possible to expand the range of final products, however, it is necessary to characterize the wood physically and anatomically to assess the alternative uses to MDF that can be achieved with wood from E. urophylla in Huimanguillo.

\section{Objective}

The objective of the work was to evaluate the basic density of the wood of Eucalyptus urophylla clones in forest plantations in Huimanguillo, Tabasco.

\section{Materials and methods}

The material used in the study was obtained from two clonal tests of E. urophylla, one of 12 years of age located in the Miguel Alemán ranch and the other of five years of age located in the Valle Verde ranch in Huimanguillo, Tabasco.

11 different genotypes were selected. The basic density of seven five-year-old genotypes was obtained by the empirical method through the extraction of wood chips with a Pressler drill. Density was estimated for the four remaining genotypes with the water displacement method.

\section{Empirical method}

The empirical method described by ValenciaManzo and Vargas-Hernández (1997) is a simple and highly reliable method to estimate the density of wood in samples that have a geometric shape. Each wood (chip) sample was considered a perfect cylinder. Wood samples were obtained from side to side of the stem with a Pressler drill with an internal diameter of $5 \mathrm{~mm}$. 
In the clones of five, samples were obtained at the height of the normal diameter at $1.30 \mathrm{~m}$ from the ground (DN), and in those of 12 years, chips were obtained at different heights of the tree: $0.30 \mathrm{~m}, 1.30 \mathrm{~m}, 50 \%$ and $75 \%$ of the total height.

Each sample was measured for length when the moisture content of the sample was above the saturation point of the fiber, immediately after being collected. The length was measured with a graduated ruler to the nearest millimeters. Each sample was stored in a plastic straw and transported in a cooler to the laboratory in order to avoid dehydration.

With the length of the sample and the internal diameter of the hole $(5 \mathrm{~mm})$, the green volume was obtained with the equation 1: 1

$\mathrm{V}_{\mathrm{v}}=\pi * \mathrm{D}^{2} *(\mathrm{~L} / 4)$

Where,

V_V = volume of the wooden cylinder $(\mathrm{cm} 3)$

$\mathrm{D}=$ inner diameter of pressler drill $(0.5 \mathrm{~cm})$

$\mathrm{L}=$ length of the wood sample $(\mathrm{cm})$

The anhydrous weight (Po) of the samples was obtained on an analytical balance after dehydrating the wood chips in an oven at $70^{\circ} \mathrm{C}$ until constant weight.

With the data of anhydrous weight (Po) and green volume $(\mathrm{Vv})$ the value of basic density of the wood $(\mathrm{Db})$ was obtained, according to equation 2 :

$\mathrm{D}_{\mathrm{b}}=\mathrm{P}_{\mathrm{o}} / \mathrm{V}_{\mathrm{v}}$

Where,

D_b = basic density $(\mathrm{g} \mathrm{cm}-3)$

P_o $=$ anhydrous weight $(\mathrm{g})$

V_V $=$ Wooden cylinder volume $(\mathrm{cm} 3)$

\section{Water displacement method}

The green volume was estimated with mode III of method B of the ATSM D2395-14 standard, which establishes the guidelines for making standard tests of density and specific gravity of wood and wood-based materials (ASTM, 2014).
Destructive sampling was made for the wood analysis. The trees were measured for total height (AT) and DN, later they were knocked down, from each tree slices of $5 \mathrm{~cm}$ thick were obtained at the height of the stump $(0.30 \mathrm{~m}), \mathrm{DN}$, 50 and $75 \%$ of the height total to see the variation in density along the stem. The slices were taken to the laboratory of the company Forestaciones Operativas de México S.A de C.V to obtain small samples of $3 \times 3 \times 3 \mathrm{~cm}$. The samples were immersed in water for a period of five days to saturate the fibers.

After this period, they were weighed on a scale with a precision of $0.001 \mathrm{~g}$ to obtain their green weight. The green volume was obtained by displacement of water as indicated in mode III of method B of the international standard D239514.

After obtaining the volume, they were placed in a drying oven to dehydrate the sample at $70^{\circ} \mathrm{C}$ until constant weight. With the green volume value and the dry weight of the sample, the density was obtained, which is the relationship between mass and volume (Equation 3).

$\rho=\mathrm{m} / \mathrm{v}$

Where,

$\rho=$ basic density $(\mathrm{g} \mathrm{cm}-3)$

$\mathrm{m}=$ dry mass of the sample obtained in the drying oven $(\mathrm{g})$

$\mathrm{v}=$ volume of the sample obtained by water displacement $(\mathrm{cm} 3)$

\section{Results and Discussion}

\section{Empirical method}

Of the clones evaluated at 5 years (Table 1), the density ranged between 0.38 and $0.53 \mathrm{~g} \mathrm{~cm}-3$. Clone 5 had the lowest density of all. Based on the NBR 11941 standard (ABNT, 2003), the density of the wood for the seven clones evaluated by the empirical method is classified from light to very light. These results are very similar to those obtained for other Eucalyptus species. Alarcón et al., (2018) estimated an average basic density of $0.42 \mathrm{~g} \mathrm{~cm}-3$ for Eucalyptus grandis in Argentina, with a range of 0.34 to $0.52 \mathrm{~g} \mathrm{~cm}-3$ as minimum and maximum values, respectively. 


\begin{tabular}{|l|c|c|c|r|}
\hline Clone & \multicolumn{1}{c}{$\begin{array}{c}\text { Length } \\
\text { (cm) }\end{array}$} & $\begin{array}{c}\text { Green } \\
\text { volume } \\
\text { (cm3) }\end{array}$ & \multicolumn{1}{c|}{$\begin{array}{c}\text { Dry } \\
\text { weight } \\
(\mathbf{g})\end{array}$} & $\begin{array}{c}\text { Density } \\
\mathbf{c m}-3)\end{array}$ \\
\hline 1 & 16.30 & 3.17 & 1.47 & 0.46 \\
\hline 2 & 14.63 & 2.87 & 1.53 & 0.53 \\
\hline 3 & 16.40 & 3.23 & 1.43 & 0.45 \\
\hline 4 & 14.15 & 2.75 & 1.25 & 0.45 \\
\hline 5 & 16.90 & 3.30 & 1.25 & 0.38 \\
\hline 6 & 16.40 & 3.20 & 1.50 & 0.48 \\
\hline 7 & 20.80 & 4.10 & 1.67 & 0.40 \\
\hline
\end{tabular}

Table 1 Basic density obtained in wood chips in five-yearold E. urophylla clones

In the 12-year-old clones (Table 2), the wood sample obtained at different heights of the tree yielded densities that ranged between 0.51 and $0.72 \mathrm{~g} \mathrm{~cm}-3$, although the vast majority of densities were in a range of 0.52 to $0.53 \mathrm{~g} \mathrm{~cm}-3$. There is no density trend at the different heights sampled. Both at the height of $0.30 \mathrm{~m}$ and at $75 \%$ of the height of the trees the densities are very similar. The density obtained by the empirical method in 12-year-old trees (Table 2) was slightly higher than that obtained in five-yearold trees (Table1).

\begin{tabular}{|c|c|c|c|c|}
\hline Clone & Section & $\begin{array}{l}\text { Green volume } \\
\quad(\mathrm{cm} 3)\end{array}$ & $\begin{array}{l}\text { Dry weight } \\
\text { (g) }\end{array}$ & $\begin{array}{c}\text { Density (g/ } \\
\text { cm3) }\end{array}$ \\
\hline \multirow[t]{4}{*}{1} & 0.30 & 6.56 & 3.38 & 0.52 \\
\hline & 1.30 & 5.99 & 3.12 & 0.52 \\
\hline & $50 \%$ & 3.46 & 1.96 & 0.57 \\
\hline & $75 \%$ & 1.98 & 1.01 & 0.51 \\
\hline \multirow[t]{4}{*}{2} & 0.30 & 6.95 & 4.34 & 0.62 \\
\hline & 1.30 & 4.59 & 2.45 & 0.53 \\
\hline & $50 \%$ & 3.97 & 2.51 & 0.63 \\
\hline & $75 \%$ & 2.49 & 1.56 & 0.63 \\
\hline \multirow[t]{4}{*}{3} & 0.30 & 0.00 & 0.00 & 0.00 \\
\hline & 1.30 & 5.71 & 3.01 & 0.53 \\
\hline & $50 \%$ & 3.93 & 2.13 & 0.54 \\
\hline & $75 \%$ & 2.63 & 1.42 & 0.54 \\
\hline \multirow[t]{4}{*}{4} & 0.30 & 6.58 & 4.73 & 0.72 \\
\hline & 1.30 & 6.75 & 3.69 & 0.55 \\
\hline & $50 \%$ & 4.01 & 2.20 & 0.55 \\
\hline & $75 \%$ & 2.47 & 1.47 & 0.59 \\
\hline
\end{tabular}

Table 2 Basic density obtained from wood chips of 12year-old E. urophylla clones

This characteristic may be associated with a greater amount of juvenile wood in the five-year-old clones compared to a greater amount of late wood in the 12-year-old clones (Blanco-Flórez et al., 2014).

\section{Water displacement method}

The wood density of the clones estimated by this method ranged from 0.49 to $0.63 \mathrm{~g} \mathrm{~cm}-3$. However, the large proportion of the density fluctuated between 0.54 and $0.56 \mathrm{~g} \mathrm{~cm}-3$ at 12 years of age of the trees.
Taking the NBR 11941 (ABNT, 2003) standard as the reference, the density values at the different heights of the tree are classified from light to very light.

\begin{tabular}{|c|c|c|c|c|c|}
\hline Clone & Section & $\begin{array}{c}\text { Green } \\
\text { Weight } \\
\text { (g) }\end{array}$ & $\begin{array}{c}\text { Green } \\
\text { volume } \\
(\mathrm{cm} 3)\end{array}$ & $\begin{array}{c}\text { Dry } \\
\text { weight } \\
\text { (g) }\end{array}$ & $\begin{array}{c}\text { Density } \\
(\mathrm{g} / \mathrm{cm} 3)\end{array}$ \\
\hline \multirow[t]{4}{*}{1} & $0.3 \mathrm{~m}$ & 32.70 & 29.22 & 15.12 & 0.52 \\
\hline & $1.3 \mathrm{~m}$ & 33.58 & 30.98 & 15.88 & 0.51 \\
\hline & $50 \%$ & 33.85 & 31.53 & 17.42 & 0.56 \\
\hline & $75 \%$ & 27.25 & 25.67 & 13.80 & 0.54 \\
\hline \multirow[t]{4}{*}{2} & $0.3 \mathrm{~m}$ & 31.33 & 29.13 & 18.35 & 0.63 \\
\hline & $1.3 \mathrm{~m}$ & 32.22 & 31.45 & 16.93 & 0.54 \\
\hline & $50 \%$ & 27.00 & 27.50 & 15.18 & 0.55 \\
\hline & $75 \%$ & 28.82 & 28.90 & 16.20 & 0.56 \\
\hline \multirow[t]{4}{*}{3} & 0.3 & 34.90 & 36.17 & 19.77 & 0.54 \\
\hline & 1.3 & 29.65 & 30.65 & 15.85 & 0.53 \\
\hline & $50 \%$ & 21.00 & 21.73 & 11.90 & 0.55 \\
\hline & $75 \%$ & 21.90 & 22.83 & 16.20 & 0.56 \\
\hline \multirow[t]{4}{*}{4} & 0.3 & 37.15 & 35.25 & 18.25 & 0.52 \\
\hline & 1.3 & 34.50 & 35.00 & 16.75 & 0.49 \\
\hline & $50 \%$ & 26.95 & 27.00 & 13.10 & 0.49 \\
\hline & $75 \%$ & 26.90 & 26.00 & 13.95 & 0.54 \\
\hline
\end{tabular}

Table 3 Basic wood density of E. urophylla clones from the 12-year trial obtained using the water displacement technique

In general, the results of the basic density of Eucalyptus urophylla clones obtained in Huimanguillo is similar to that obtained in other eucalyptus studies. Omonte et al., (2019) obtained densities between 0.41 and $0.56 \mathrm{~g} \mathrm{~cm}$ 3 in 18-year-old Eucalyptus nitens trees in Chile. Igartúa and Monteoliva, (2010) estimated densities between 0.42 to $0.61 \mathrm{~g} \mathrm{~cm}-3$ in Eucalyptus globulus trees in Argentina. The range of basic density obtained in this study was similar to that obtained by Alarcón et al., (2018), who obtained values of 0.32 to $0.70 \mathrm{~g} \mathrm{~cm}-3$ of basic density using three different methods in three Eucalyptus species in Argentina.

The results obtained in this study are comparable with almost all those carried out for eucalyptus as mentioned above, however, when they are compared with other forest species the results are inferior. Muñoz et al., (2019) estimated the basic density for 59 forest species with a warm climate in Brazil. The authors entered that 48 species had densities that oscillated above $0.60 \mathrm{~g} \mathrm{~cm}-3$, reaching values of up to $1.25 \mathrm{~g} \mathrm{~cm}-3$. The eleven remaining species evaluated by the authors ranged between 0.38 and $0.59 \mathrm{~g} \mathrm{~cm}-3$, very similar to those of $E$. urophylla obtained in this study. 
In general, the density obtained in both the five and 12-year-old clones fall within the range of light to very light woods according to the NBR 11941 standard (ABNT, 2003). However, even being light wood, these results encourage the production of Eucalyptus urophylla wood in Huimanguillo because the density ranges obtained in this study corroborate what was found by other authors on the diversity of uses of the wood of this species.

Since, in addition to being suitable for the production of MDF, they are also suitable for the production of pulp for paper with optimal densities ranging from $0.4 \mathrm{~g} \mathrm{~cm}-3$ to $0.6 \mathrm{~g} \mathrm{~cm}$ 3 (Downes et al., 1997; Alarcón et al., 2018), particularly the five-year-old clones that show the best densities for this use. Also, the densities obtained in 12-year-old trees are ideal for carbon production, since the wood is slightly denser than the five-year-old clones, this characteristic has direct implications since it improves the energy mass and the mechanical resistance of the charcoal (Marchesan et al., 2020).

\section{Acknowledgments}

To the research project "Early evaluation of progeny and clonal tests of the Eucalyptus urophylla species used in commercial forestry plantations of the company Forestaciones Operativas de México SA de CV in the state of Tabasco" of the Sectorial Fund for Research, Development and Forest Technological Innovation (code: A3-S-130398), for the financing granted; and to the FOMEX Company (Forestaciones Operativas de Mexico S.A de C.V) for their support.

\section{Conclusions}

The average basic density of all the clones obtained with the empirical method is $0.45 \mathrm{~g} \mathrm{~cm}-$ 3. Most of the clones showed similarity for the basic density, with values between 0.40 and 0.48 $\mathrm{g} \mathrm{cm}-3$.

With the water displacement method, the basic density ranged between 0.49 and $0.63 \mathrm{~g}$ $\mathrm{cm}-3$, obtaining an average of $0.54 \mathrm{~g} \mathrm{~cm}-3$.

The basic density obtained by the two methods is classified as liavian to very light, however, it presents ideal characteristics for the manufacture of MDF, pulp for paper, and the wood of the older clones can be used to obtain charcoal.

\section{References}

Alarcón, P. C., Fernández, M. E., Pathauer, P., Harrand, L., Oberschelp, G. P. J., Monteoliva, S., y Martinez-Meier, A. (2018). Comparación de metodologías para la estimación de la densidad de la madera y sus implicancias en la estimación de parámetros genéticos en tres especies del género Eucalyptus. Revista de La Facultad de Agronomía, La Plata, 117(2), 175183.

American Society for Testing and Materials (ASTM). (2014). ASTM D2395 - 14: standard test methods for density and specific gravity (relative density) of wood and wood-based materials. In Annual Book of ASTM Standards (pp. 1-13). https://doi.org/10.1520/D2395-17.2

Arango, B., Hoyos, J. F., y Vásquez, A. M. (2001). Variación de la densidad básica de la madera de Eucalyptus grandis en arboles de siete años de edad. Revista Facultad Nacional de Agronomía Medellín, 54(1 y 2), 1275-1284.

Associaçao Brasileira de Normas Técnicas (ABNT). (2003). NBR 11941: madeira, determinaçao da densidade básica. Rio de Janeiro: ABNT.

Blanco-Flórez, J., Fernando-Trugilho, P., Tarcisio-Lima, J., Gherardi-Hein, P. R., y Da Silva, J. R. M. (2014). Caracterización de la madera joven de Tectona grandis L. f. plantada en Brasil. Madera y Bosques, 20(1), 11-20. https://doi.org/10.21829/myb.2014.201172

Comisión Nacional Forestal (CONAFOR), y Asociación Mexicana de Plantadores Forestales (AMEPLANFOR). (2016). Situación actual del germoplasma utilizado en los programas de plantaciones forestales comerciales en el sureste de México.

Eufrade-Junior, H. de J., Ballarin, A. W., Villamagua-Vergara, G. C., y Guerra, S. P. S. (2017). Efecto del manejo silvícola sobre la densidad básica de la madera en sistemas forestales de rotación corta. Maderas: Ciencia y Tecnologia, 19(3), 285-292. https://doi.org/10.4067/S0718221X2017005000 024 
Igartúa, D., y Monteoliva, S. (2010). Densidad básica, longitud de fibras y crecimiento en dos procedencias de Eucalyptus globulus en Argentina. Bosque, 31(2), 150-156. https://doi.org/10.4067/s071792002010000200

008

Lahr, F. A. R., Nogueira, M. C. D. J. A., De Araujo, V. A., Vasconcelos, J. S., and Christoforo, A. L. (2017). Physical-mechanical characterization of Eucalyptus urophylla wood. Engenharia Agricola, 37(5), 900-906. https://doi.org/10.1590/1809-4430-

Eng.Agric.v37n5p900-906/2017

Marchesan, R., de Oliveira, D. N., da Silva, R. C., de Carvalho, L. A., Gomes, R. T., and Almeida, V. C. (2020). Quality of charcoal from three species of the Eucalyptus and the Corymbia citriodora species planted in the south of Tocantins. FLORESTA, 50(3), 1643-1652. https://doi.org/10.5380/rf.v50i3.65303

Muñoz, G. R., Encinas, J. I., y de Paula, J. E. (2019). Densidad de la madera de 59 especies del orden Sapindales procedentes de bosques naturales brasileños. Madera y Bosques, 25(2), 2521817.

https://doi.org/10.21829/myb.2019.2521817

Omonte, M., Sáez-Carrillo, K., Ananías, R. A., y Valenzuela-Hurtado, L. (2019). Variación del contenido de humedad verde y de la densidad básica de la madera en árboles de Eucalyptus nitens. Maderas: Ciencia y Tecnologia, 21(3), 413-424.

https://doi.org/10.4067/S0718221X2019005000 313

Souza, F. M. L., Sansígolo, C. A., Pupo, C. H., and Sereghetti, G. C. (2017). Wood and pulping properties of Eucalyptus urophylla and its hybrid grown by silvopastoral and conventional forest production models. Cellulose Chemistry and Technology, 51(3-4), 347-353.

Valencia-Manzo, S., y Vargas-Hernández, J. (1997). Método empírico para estimar la densidad básica en muestras pequeñas de madera. Madera y Bosques, 3(1), 81-87. https://doi.org/10.21829/myb.1997.311381 